\title{
Palladium and platinum organochalcogenolates and their transformation into metal chalcogenides
}

\author{
S DEY, S NARAYAN, A SINGHAL and V K JAIN* \\ Novel Materials and Structural Chemistry Division, Bhabha Atomic Research \\ Centre, Trombay, Mumbai 400 085, India \\ e-mail: jainvk@apsara.barc.ernet.in
}

\begin{abstract}
Platinum group metal chalcogenides find extensive applications in catalysis and in the electronic industry. To develop an efficient low temperature clean preparation of these materials, molecular routes have been explored. Thus the chemistry of mononuclear organochalcogenolates of the type $\left[\mathrm{M}\left(\mathrm{ER} \Phi_{2}\left(\mathrm{PR}_{3}\right)_{2}\right]\right.$, binuclear benzylselenolates, $\left[\mathrm{M}_{2} \mathrm{Cl}_{2}(\mathrm{mSeBz})_{2}\left(\mathrm{PR}_{3}\right)_{2}\right]$, allylpalladium complexes $\left[\mathrm{Pd}_{2}(\mathrm{mER})_{2}\left(\mathrm{~h}^{3}-\mathrm{C}_{4} \mathrm{H}_{7}\right)_{2}\right]$ and palladium/platinum sulphido/selenido-bridged complexes, $\left[\mathrm{M}_{2}(\mathrm{mE})_{2} \mathrm{~L}_{4}\right](\mathrm{M}=\mathrm{Pd}$ or $\mathrm{Pt} ; \mathrm{E}=\mathrm{S}$, Se or Te; $\mathrm{L}=$ tertiary phosphine ligand) has been investigated. All the complexes have been characterized by elemental analysis, NMR $\left({ }^{1} \mathrm{H},{ }^{31} \mathrm{P},{ }^{77} \mathrm{Se},{ }^{195} \mathrm{Pt}\right)$ spectroscopy and in some cases by X-ray diffraction. The thermal behaviour of these complexes has been studied by TGA. The pyrolysis of allylpalladium complexes in refluxing xylene yields $\mathrm{Pd}_{4} \mathrm{E}$ as established by analysis and XRD patterns.
\end{abstract}

Keywords. Palladium; platinum; organochalcogenolates; chalcogenides; NMR.

\section{Introduction}

Platinum group metal chalcogenides $\left(\mathrm{M}_{x} \mathrm{E}_{y} ; \mathrm{M}=\right.$ platinum group metal; $\left.\mathrm{E}=\mathrm{S}, \mathrm{Se}, \mathrm{Te}\right)$ find extensive applications in catalysis ${ }^{1-4}$ and materials science ${ }^{5-8}$. Examples of the latter include manufacture of semiconductors, solar cells ${ }^{5}$, high resolution lithographic films/ plates ${ }^{6}$, optical disc recording films ${ }^{7}$, etc. The continuing drive for scaling down of these device dimensions has motivated research in design and development of organometallic precursor chemistry. This has, in turn, led to an ever increasing number of organometallic precursor molecules which show lower growth temperatures and cleaner depositions.

Platinum group metal organochalcogenolates are attractive not only because of their possible role as molecular precursors for metal chalcogenides but also for their rich reaction chemistry and structural diversity. Some of our results on these molecules are discussed here.

\section{Mononuclear complexes}

Reaction of $\left[\mathrm{MCl}_{2}(\mathrm{~L}-\mathrm{L})\right]$ with mercaptans in the presence of triethylamine readily give mononuclear complexes $\left[\mathrm{M}\left(\mathrm{SR}^{\prime}\right)_{2}(\mathrm{~L}-\mathrm{L})\right]$. The selenolato and tellurolato complexes have been obtained by the reaction of $\left[\mathrm{MCl}_{2}(\mathrm{~L}-\mathrm{L})\right]$ with sodium salt of organochalcogenolates in benzene-methanol mixture. The selenolato platinum complex can be obtained by oxidative addition of diphenyldiselenide on a platinum( 0 ) complex (scheme 1$)^{9-12}$.

*For correspondence 
Scheme 1.

These complexes with monodentate phosphine ligands are usually formed as the trans product, but in certain cases cis-derivatives can also be isolated which slowly isomerize to the trans form. The complexes with chelating phosphines (dppm, dppe, dppp), as expected, adopt a cis configuration. The ${ }^{31} \mathrm{P}$ NMR spectra exhibit a single resonance which is shielded relative to the corresponding dichloride. The resonance showed chalcogen dependence with shielding as $\mathrm{S}$ is replaced by Se and then Te. However, this trend is less prominent in the corresponding platinum complexes. The spectra of the latter are flanked with ${ }^{195} \mathrm{Pt}$ satellites. The magnitude of ${ }^{1} J(\mathrm{Pt}-\mathrm{P})$ is reduced significantly as compared to the corresponding dichlorides, reflecting high trans influence of the ER' groups. Since the trans influences for tertiary phosphines and organochalcogenides are comparable, the ${ }^{1} J(\mathrm{Pt}-\mathrm{P})$ values are expected to have similar magnitudes for the cis and trans isomers in the case of monodentate phosphine complexes. This observation poses difficulties in unambiguous identification of isomers formed for the thiolato complexes. However, both ${ }^{77} \mathrm{Se}$ and ${ }^{125} \mathrm{Te}$ nuclei have naturally occurring NMR active isotopes and hence the magnitude of ${ }^{2} J\left({ }^{77} \mathrm{Se} /{ }^{125} \mathrm{Te}-{ }^{31} \mathrm{P}\right)$ would enable identification of which isomer is formed. Thus the ${ }^{31} \mathrm{P}$ NMR spectra of the complexes showing such couplings have been characterized as cis complexes. The ${ }^{1} J(\mathrm{Pt}-\mathrm{P})$ values are highly dependent on the nature of $\mathrm{PR}_{3}, \mathrm{E}$ and $\mathrm{R}^{\prime}$ groups. The magnitude of ${ }^{1} J(\mathrm{Pt}-\mathrm{P})$ increases in the following order of $\mathrm{PR}_{3}$, $\mathrm{E}$ and $\mathrm{R}^{\prime}$ ligands, keeping other groups unchanged.

$$
\begin{aligned}
& \mathrm{PR}_{3}=\mathrm{PEt}_{3}<\mathrm{PBu}_{3}<\mathrm{PMe}_{2} \mathrm{Ph}<\mathrm{PMePh}_{2}<\mathrm{PPh}_{3} \\
& \mathrm{R}^{\prime}=4-\mathrm{ClC}_{6} \mathrm{H}_{4}<\mathrm{Ph}<\text { tol }<\mathrm{Pr}^{\mathrm{i}}<\mathrm{Et} \\
& \mathrm{E}=\mathrm{Te}<\mathrm{Se}<\mathrm{S} .
\end{aligned}
$$

The ${ }^{77} \mathrm{Se}\left\{{ }^{1} \mathrm{H}\right\}$ NMR spectra of several complexes have been recorded. The cis complexes showed doublets while for the trans product a triplet was observed. In the case of platinum complexes ${ }^{2} J(\mathrm{Se}-\mathrm{P})_{\text {cis }}$ are small $(\sim 7 \mathrm{~Hz})$. These complexes showed platinum satellites $\left[{ }^{1} J(\mathrm{Pt}-\mathrm{Se})=100-160 \mathrm{~Hz}\right]$ (figure 1).

The ${ }^{195} \mathrm{Pt}\left\{{ }^{1} \mathrm{H}\right\}$ NMR spectra exhibit a triplet in the range $\mathrm{d}-4035$ to $-5310 \mathrm{ppm}$ due to coupling with phosphorus nuclei (figure 2). The ${ }^{195} \mathrm{Pt}$ NMR resonances are shielded on substituting dppm for dppe. For dppe and monodentate phosphine complexes resonances appear in a narrow range. The signal is shielded as sulphur is substituted for selenium and then tellurium, a trend in accord with the binding ability of the chalcogenide group (i.e. $\mathrm{SR} \phi<\operatorname{SeR} \phi<\mathrm{TeR} \phi$. 

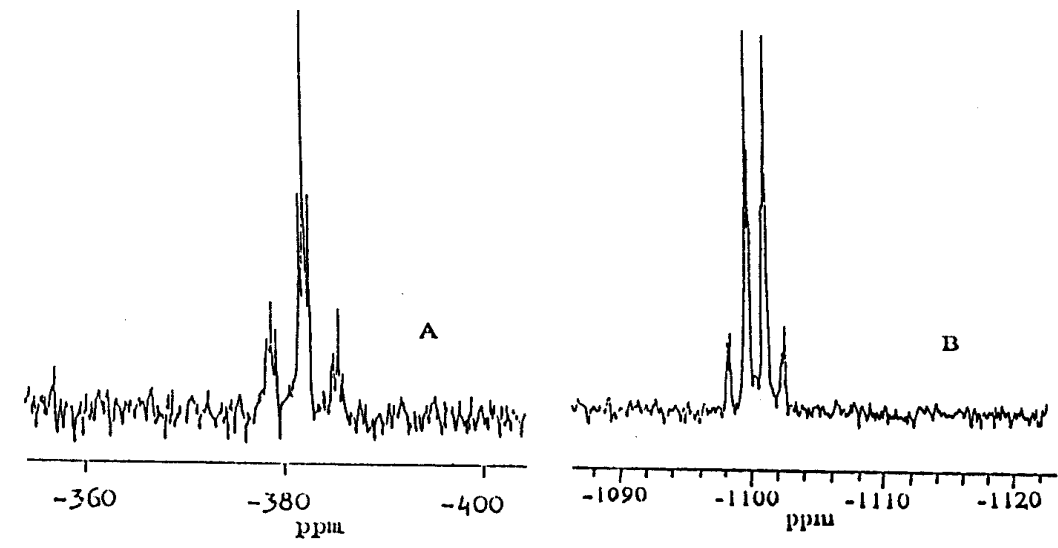

Figure 1. ${ }^{77} \mathrm{Se}\left\{{ }^{1} \mathrm{H}\right\} \quad \mathrm{NMR}$ spectra of (A) trans-[Pt( $\left.\left.\mathrm{SePh}\right)_{2}\left(\mathrm{PBu}_{3}\right)_{2}\right]$, (B) cis$\left[\mathrm{Pt}(\mathrm{SePh})_{2}(\mathrm{dppe})\right]$ in $\mathrm{CDCl}_{3}$.

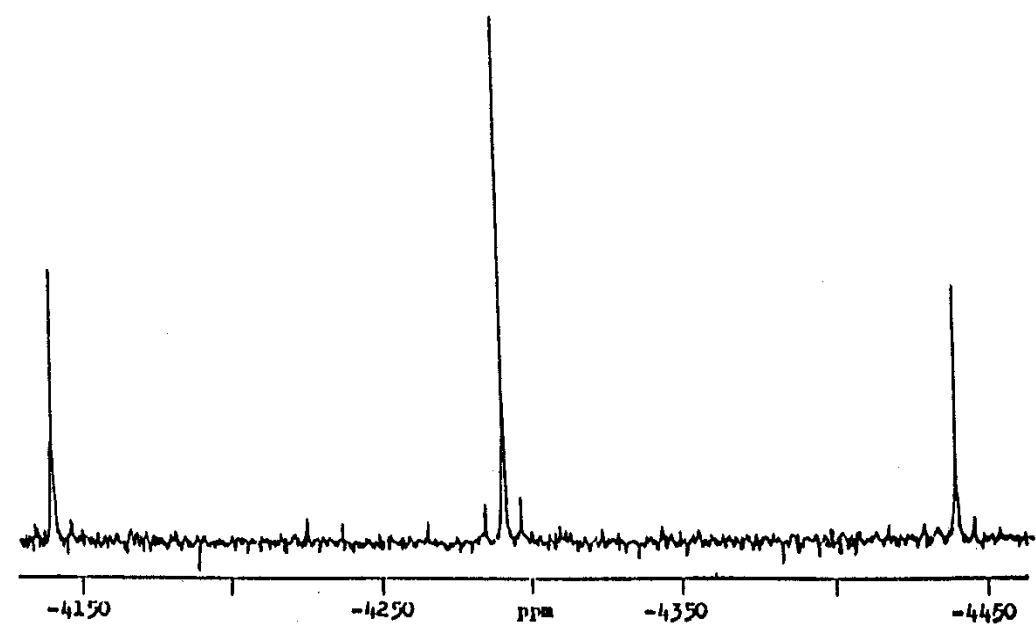

Figure 2. ${ }^{195} \mathrm{Pt}\left\{{ }^{1} \mathrm{H}\right\}$ NMR spectrum of $\left[\mathrm{Pt}(\mathrm{SePh})_{2}(\mathrm{dppm})\right]$.

Structures of $\left[\mathrm{Pt}(\mathrm{SePh})_{2}\left(\mathrm{PPh}_{3}\right)_{2}\right], \quad\left[\mathrm{Pd}\left(\mathrm{SC}_{6} \mathrm{~F}_{5}\right)_{2}(\mathrm{dppe})\right], \quad\left[\mathrm{Pd}(\mathrm{SePh})_{2}(\mathrm{dppe})\right] \quad$ and $\left[\mathrm{Pt}(\mathrm{SePh})_{2}(\mathrm{dppm})\right]$ have been established by X-ray diffraction methods. The metal atoms in these molecules adopt a distorted square planar configuration defined by two chalcogen and two phosphorus atoms.

\section{Binuclear complexes}

Several binuclear complexes, both neutral and cationic, have been prepared either by employing mononuclear precursors or a binuclear species. The uncoordinated nitrogen 


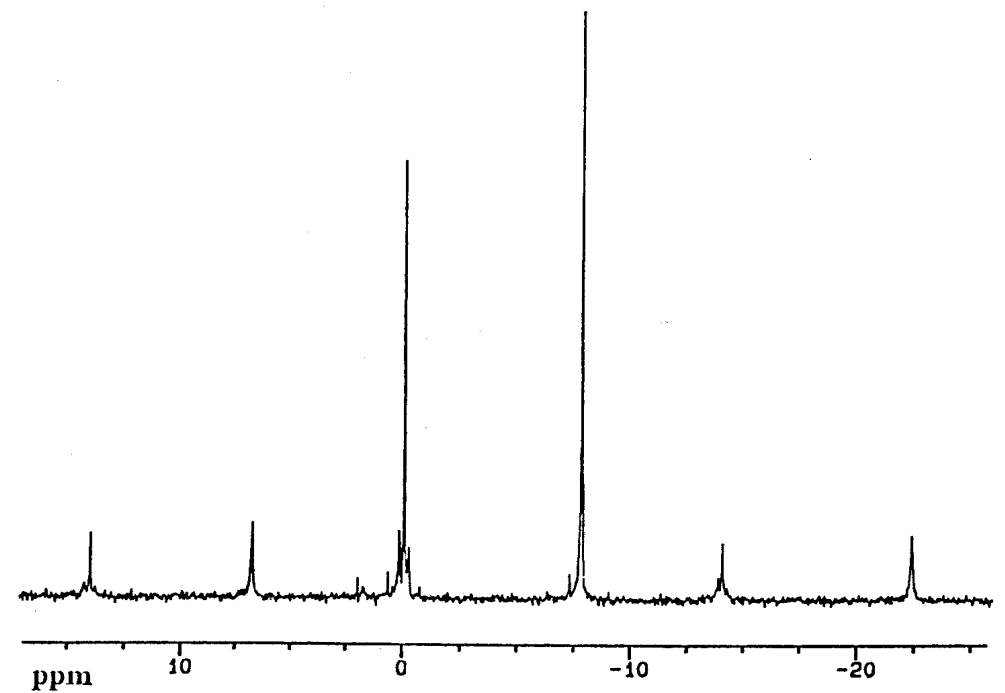

Figure 3. ${ }^{31} \mathrm{P}$ NMR spectrum of $\left[\mathrm{PtCl}_{2}\left(\mathrm{PPr}_{3}\right)(\mathrm{Sepy}) \mathrm{PtCl}\left(\mathrm{PPr}_{3}\right)\right]$.

atoms in $\left[\mathrm{M}(\mathrm{Sepy})_{2}(\mathrm{dppe})\right]^{13}$ can be employed for ligation. Thus the reaction of $\left[\mathrm{M}(\mathrm{Sepy})_{2}(\mathrm{dppe})\right]$ with $\left[\mathrm{M} \mathrm{Cl}_{2}(\mathrm{MeCN})_{2}\right]$ gives orange-to-brown coloured insoluble solids of composition [(dppe)M(Sepy $\left.)_{2} \mathrm{M} C l_{2}\right]^{14}(1)$. The IR spectra showed bands in the region 280-313 $\mathrm{cm}^{-1}$ assignable to $\mathrm{UM}-\mathrm{Cl}$ absorptions which were absent for [M(Sepy $)_{2} \mathrm{dppe}$. Yet another series of neutral binuclear complexes $\left[\mathrm{MCl}_{2}\left(\mathrm{PR}_{3}\right)(\operatorname{Sepy}) \mathrm{MCl}\left(\mathrm{PR}_{3}\right)\right]$ with single selenium bridges have been isolated (2) ${ }^{14}$. The palladium complex has been attributed a trans-chloride structure while the platinum complex has been assigned a cisconfiguration (figure 3 ).

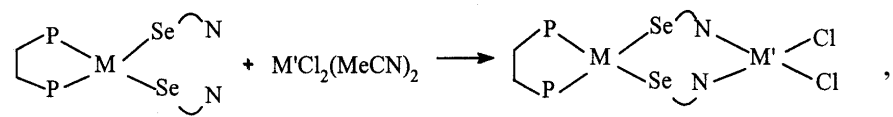

where, $\mathrm{M}, \mathrm{M} \phi=\mathrm{Pd}, \mathrm{Pd} ; \mathrm{Pt}, \mathrm{Pd} ; \mathrm{Pt}$, Pt. $\mathrm{Se}^{« N}=2-$ pySe

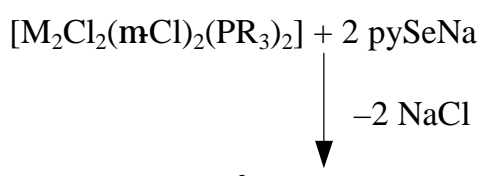

$\left[\mathrm{MCl}\left(\mathrm{h}^{2}-\mathrm{Sepy}\right)\left(\mathrm{PR}_{3}\right)\right]_{n}$

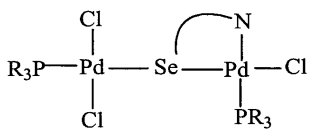

$(\mathrm{M}=\mathrm{Pd})$

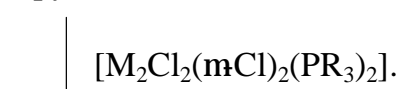

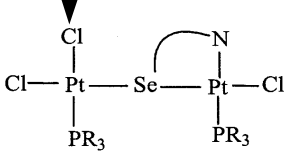

$(\mathrm{M}=\mathrm{Pt})$ 


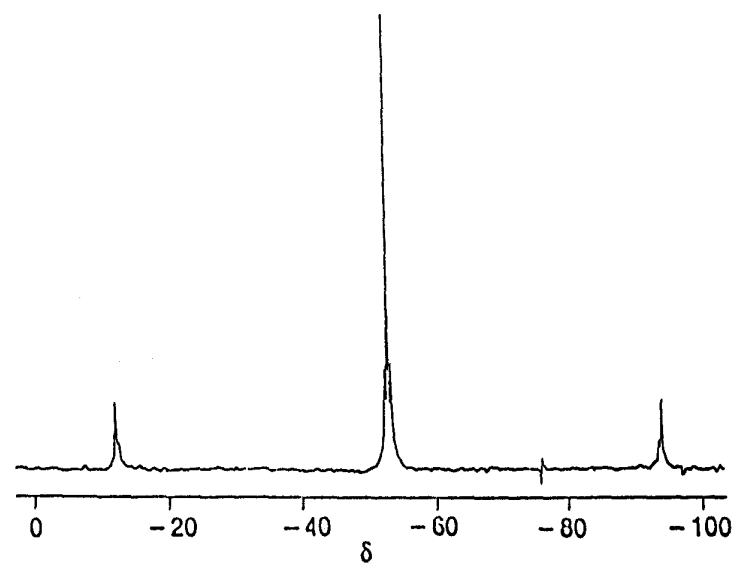

Figure 4. ${ }^{31} \mathrm{P} \mathrm{NMR}$ spectrum of $\left[\mathrm{Pt}_{2}(\mathrm{mSePh})_{2}(\mathrm{dppm})_{2}\right]\left[\mathrm{BPh}_{4}\right]_{2}$.

Several cationic binuclear complexes from mononuclear precursors have been prepared $(3)^{9,11}$. The ${ }^{31} \mathrm{P}$ NMR spectra of each of the binuclear complexes exhibit a single resonance which is deshielded from the corresponding signal for the respective mononuclear complex. Similarly, deshielding is observed for the ${ }^{195} \mathrm{Pt}$ NMR signals. For example, the ${ }^{195} \mathrm{Pt}$ resonances for $\left[\mathrm{Pt}(\mathrm{SePh})_{2}(\mathrm{dppe})\right]$ and $\left[\mathrm{Pt}_{2}(\mathrm{mSePh})_{2}(\mathrm{dppe})_{2}\right]\left[\mathrm{BPh}_{4}\right]_{2}$ appear at $\mathrm{d}-4975$ and $-4544 \mathrm{ppm}$, respectively. The presence of ${ }^{3} \mathrm{~J}(\mathrm{Pt}-\mathrm{P})(\sim 30 \mathrm{~Hz})$ in ${ }^{31} \mathrm{P}$ NMR spectra and ${ }^{2} \mathrm{~J}(\mathrm{Pt}-\mathrm{Pt})(\sim 650 \mathrm{~Hz})$ in ${ }^{195} \mathrm{Pt}$ NMR spectra indicates the formation of binuclear complexes (figure 4 ).

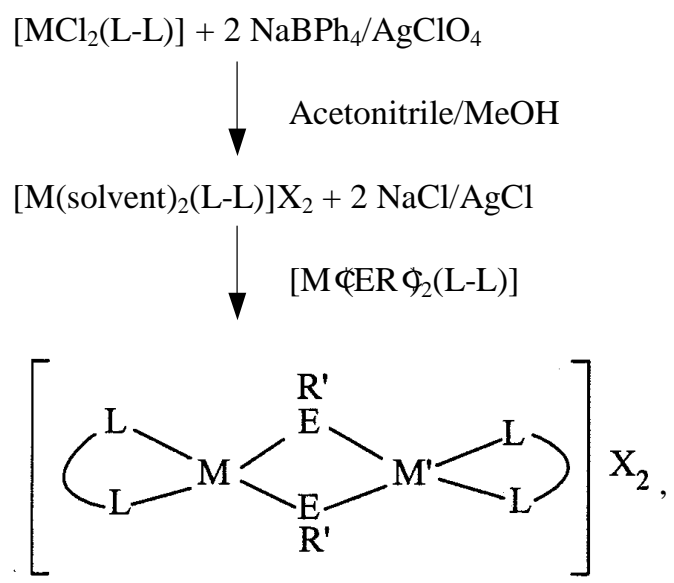

where, $\mathrm{M}, \mathrm{M} \phi=\mathrm{Pd}$ or $\mathrm{Pt} ; \mathrm{L}-\mathrm{L}=\mathrm{dppm}, \mathrm{dppe} ; \mathrm{ER} \phi=\mathrm{SPr}{ }^{\mathrm{i}}, \mathrm{SPh}, \mathrm{Stol}, \mathrm{SePh}, \mathrm{SeBz}$, $\mathrm{TeC}_{6} \mathrm{H}_{4} \mathrm{OEt}-4 ; \mathrm{X}=\mathrm{ClO}_{4}, \mathrm{BPh}_{4}$.

Several binuclear organochalcogenide-bridged complexes can be isolated from binuclear precursors. Benzylselenido-bridged $\mathrm{Pd} / \mathrm{Pt}$ complexes and allylpalladium complexes are of particular interest as both benzyl and allyl groups are known to cleave cleanly and would thus provide a convenient way to prepare metal chalcogenides. Several benzylselenido-bridged palladium and platinum complexes have been prepared (scheme 
2) and characterized. These complexes exist in cis and trans-isomeric forms as shown by NMR spectroscopy ${ }^{12}$.

Treatment of chloro-bridged allylpalladium dimer with $\mathrm{Pb}(\mathrm{ER})_{2}$ or $\mathrm{Hg}(\mathrm{TeR})_{2}$ in acetone affords organochalcogenide bridged palladium complexes $\left[\mathrm{Pd}_{2}(\mathrm{mER})_{2}\left(\mathrm{~h}^{3}-\right.\right.$ allyl $\left.)_{2}\right]^{15,16}$ (scheme 3). The tellurolato-bridged complex is unstable and decomposes at room temperature to $\mathrm{Pd}_{3} \mathrm{Te}_{2}$ (from XRD and $\mathrm{Pd}$ analysis) while thiolato and selenolatobridged complexes are stable but tend to darken with time and eventually become black. The NMR spectra of ER bridged complexes indicate the presence of both syn and antiisomers in solution. In some cases isomerization is too slow on the NMR time-scale to give separate resonances for two isomeric forms, while in others, the process is relatively

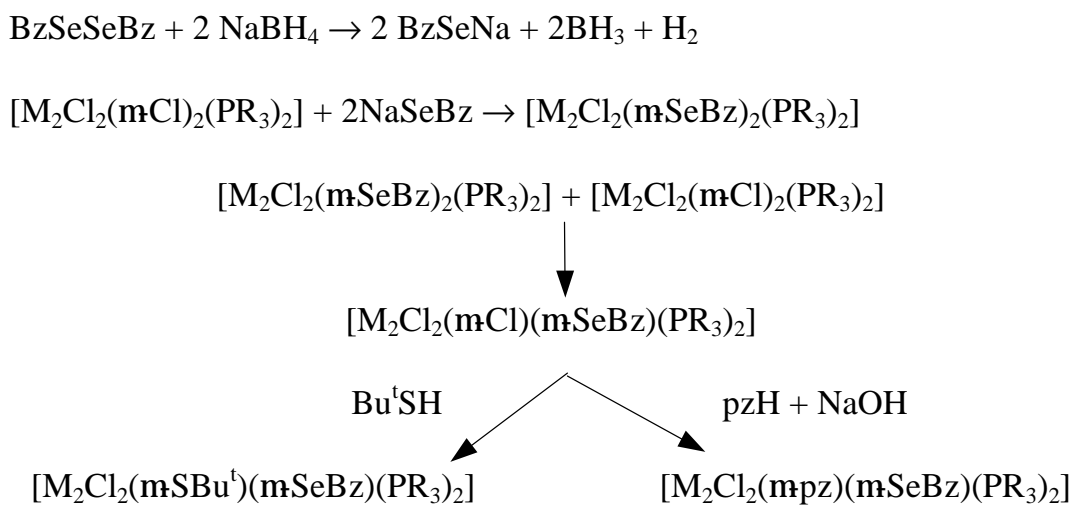

Scheme 2.

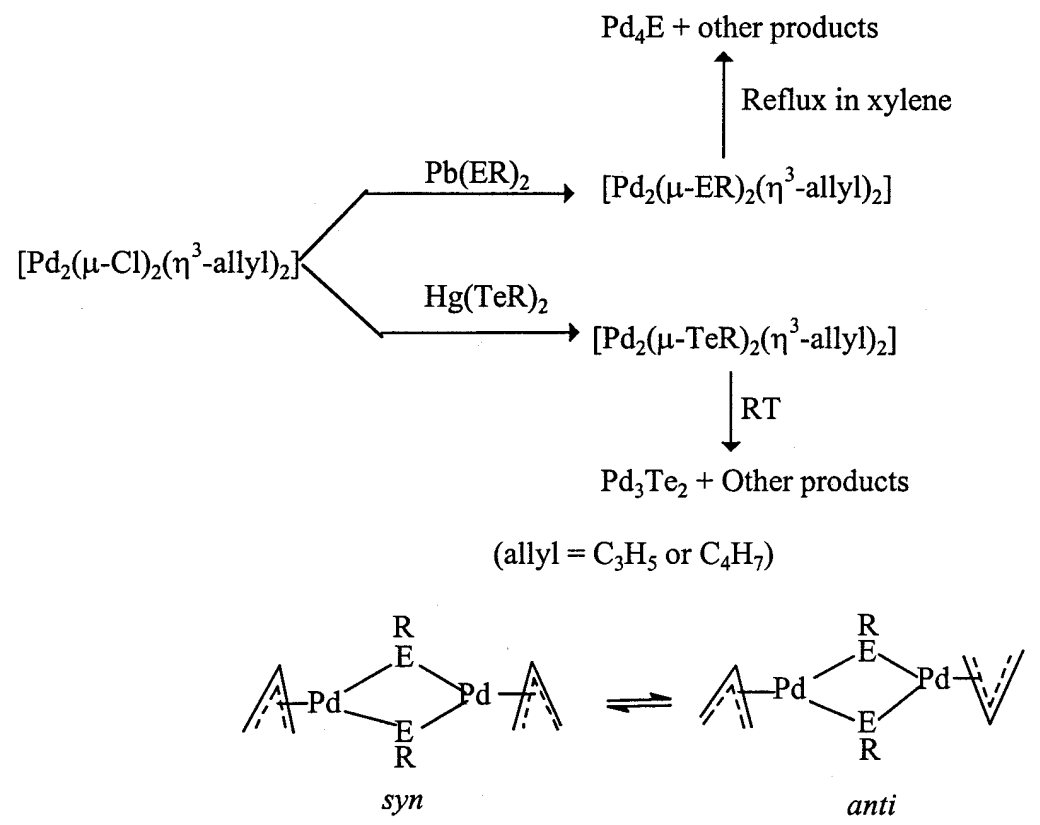

Scheme 3. 
rapid resulting in broad signals at room temperature. In such cases separate resonances can be observed at lower temperatures ${ }^{15}$.

Thermal studies on methylallylpalladium complexes were undertaken. The thermogravimetric analysis reveal that the thiolato and selenolato-bridged complexes decompose in four stages to give $\mathrm{Pd}_{4} \mathrm{E}$. Their decomposition in refluxing xylene proceeds smoothly to give $\mathrm{Pd}_{4} \mathrm{E}(\mathrm{E}=\mathrm{S}$ or $\mathrm{Se}$ ) as revealed by XRD and Pd analysis. The SEM picture shows that these materials are microcrystalline in nature.

\section{Trinuclear complexes}

Three square planes of palladium(II) and platinum(II) in trinuclear complexes can be assembled in the following ways.

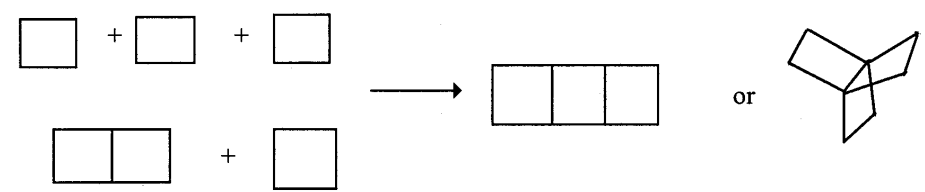

Several trinuclear palladium(II) complexes stabilized with sulphido or selenidobridged $\left[\mathrm{Pd}_{2}(\mathrm{mE})_{2}\left\{\mathrm{~S}_{2} \mathrm{P}(\mathrm{OR})_{2}\right\}_{2}\left(\mathrm{PPh}_{3}\right)_{2}\right]$ have been prepared (scheme 4) ${ }^{17}$.

The analytical and FAB mass spectral data are consistent with trinuclear formulation. In ${ }^{1} \mathrm{H}$ NMR spectra two sets of OR proton resonances in 1:1 ratio are observed. The

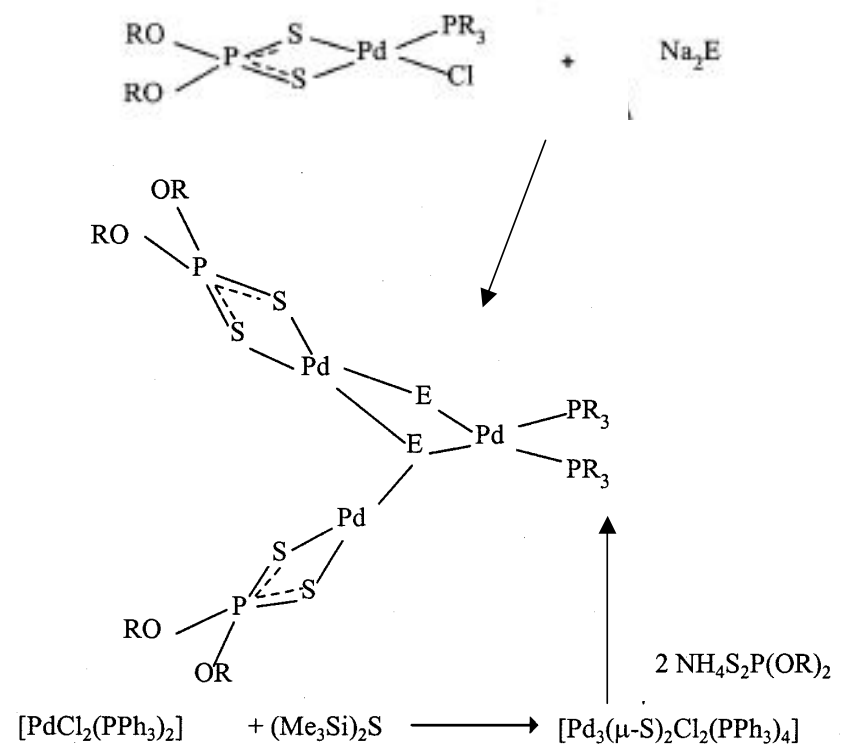

Scheme 4. 

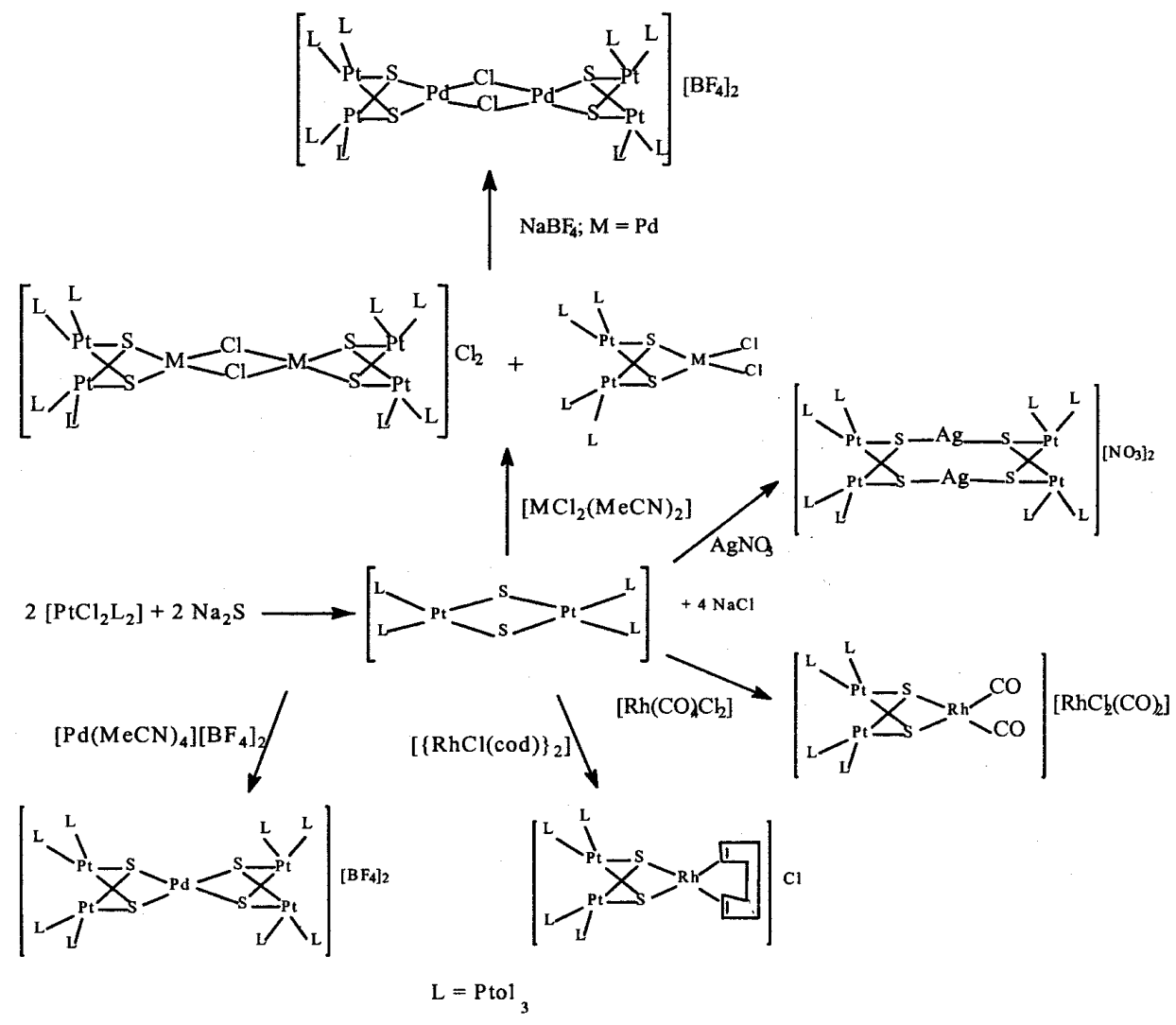

Scheme 5 .

${ }^{31} \mathrm{P}$ NMR spectra show singlets for $\mathrm{PPh}_{3}$ and $\mathrm{S}_{2} \mathrm{P}(\mathrm{OR})_{2}$. The ${ }^{77} \mathrm{Se}\left\{{ }^{1} \mathrm{H}\right\}$ NMR spectrum of $\left[\mathrm{Pd}_{3}(\mathrm{mSe})_{2}\left\{\mathrm{~S}_{2} \mathrm{P}\left(\mathrm{OPr}^{\mathrm{n}}\right)_{2}\right\}_{2}\left(\mathrm{PPh}_{3}\right)_{2}\right]$ exhibits a doublet at $\mathrm{d}-98.7 \mathrm{ppm}$ with ${ }^{2} \mathrm{~J}(\mathrm{Se}-$ $\mathrm{P})_{\text {trans }}=48 \mathrm{~Hz}$. The molecular structure of $\left[\mathrm{Pd}_{3}(\mathrm{mS})_{2}\left\{\mathrm{~S}_{2} \mathrm{P}(\mathrm{OEt})_{2}\right\}_{2}\left(\mathrm{PPh}_{3}\right)_{2}\right]$, established by X-ray crystallography, consists of three distorted square planar palladium atoms sharing two $\mathrm{m}-\mathrm{S}$ ligands ${ }^{17}$. The TG analyses on several of these complexes have been carried out. These complexes show multiple fragmentation pattern finally leading to $\mathrm{Pd}_{3} \mathrm{ES}(\mathrm{E}=\mathrm{S} \text { or Se })^{18}$.

The fragment ' $\left[\mathrm{Pd}_{2}(\mathrm{mE})_{2}\right]$ ' in the above molecules is analogous to $\left[\mathrm{Pt}_{2}(\mathrm{mS})_{2} \mathrm{~L}_{4}\right]$ $\left(\mathrm{L}=\mathrm{PPh}_{3}, \mathrm{Ph}_{2} \mathrm{pyP}, 1 / 2 \mathrm{dppe}\right)^{19}$. The sulphur lone pair in the latter molecules is sufficiently basic and can be compared with bidentate thioethers. Therefore these molecules can function as a metallo-ligand. Thus a soluble sulphido-bridged binuclear precursor $\left[\mathrm{Pt}_{2}(\mathrm{mS})_{2}\left(\mathrm{Ptol}_{3}\right)_{4}\right]$ has been prepared (scheme 5). The NMR data are consistent to binuclear formulation (figure 5) ${ }^{20}$. The sulphido-bridged dimer can be used as a metallo ligand. Accordingly, it reacts with several metal complexes to yield tri-, tetraand high-nuclearity metal aggregates (scheme 5). On coordination, the ${ }^{31} \mathrm{P}$ NMR signal of $\left[\mathrm{Pt}_{2}(\mathrm{mS})_{2}\left(\mathrm{Ptol}_{3}\right)_{4}\right]$ is shielded by $\sim 10 \mathrm{ppm}$ whereas the magnitude of ${ }^{1} \mathrm{~J}(\mathrm{Pt}-\mathrm{P})$ increases by $178-418 \mathrm{~Hz}$. The increase in ${ }^{1} \mathrm{~J}(\mathrm{Pt}-\mathrm{P})$ coupling constant indicates a diminished polarizability of the Pt-S bond as a consequence of the non-bonding electron-pair donation to the incoming metal atom. 

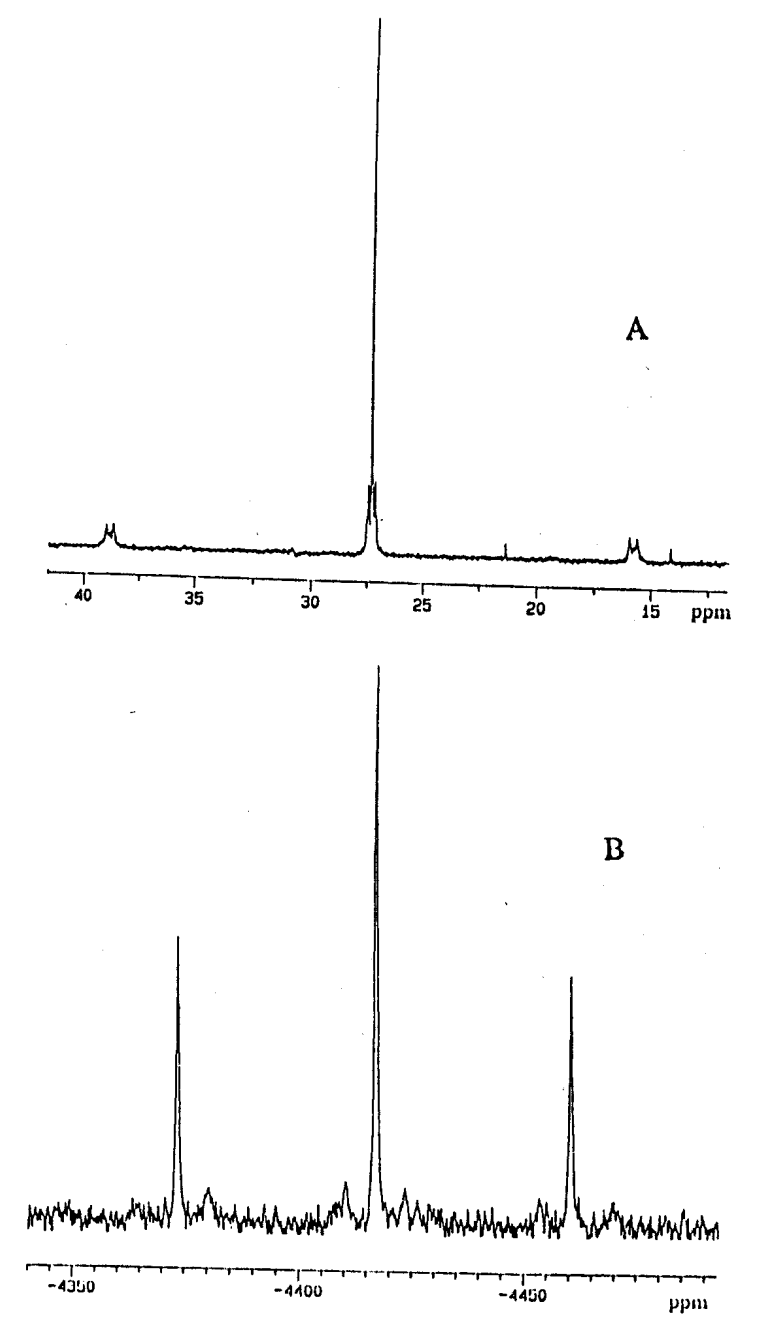

Figure 5. ${ }^{31} \mathrm{P}$ and ${ }^{195} \mathrm{Pt} \mathrm{NMR}$ spectra of $\left[\mathrm{Pt}_{2}(\mathrm{mS})_{2}\left(\mathrm{Ptol}_{3}\right)_{4}\right]$.

Binuclear tellurido-bridged complexes have also been isolated (4). Further work is in progress $^{21}$.

$$
\begin{aligned}
& \mathrm{PBu}_{3}+\mathrm{Te} \rightarrow \mathrm{PBu}_{3} \mathrm{Te} \\
& {\left[\mathrm{Pt}(\text { dppe })_{2}\right]+\mathrm{PBu}_{3} \mathrm{Te} \rightarrow 1 / 2\left[\mathrm{Pt}_{2}(\mathrm{mTe})_{2}(\text { dppe })_{2}\right]+\text { dppe }+\mathrm{PBu}_{3} .}
\end{aligned}
$$

\section{Acknowledgements}

We are thankful to Drs J P Mittal and P Raj for encouragement of this work. We are also grateful to Drs Babu Varghese, E R T Tiekink, R J Butcher, R Bohra and J P Jasinski for stimulating collaboration. 


\section{References}

1. Chiang L Y, Sioirczeweki J W, Kastrup R, Hsu C S and Upasani R B 1991 J. Am. Chem. Soc. 1136574

2. Eijsbouts S, DeBeer V H J and Prins R 1988 J. Catal. 109217

3. Mitshubishi Chemical Corp 1998 Jpn. Appl. 10/36315 (through Platinum Met. Rev. 199842 131); European Appl. 904836A (through Platinum Met. Rev. 199943 134)

4. Misono M and Nojiri N 1990 Appl. Catal. 641

5. Yamamoto T 1986 Jpn. Pat. 61215661; Chem. Abstract $198710687694 \mathrm{~h}$

6. Idota Y and Yogihara M 1986 Fuji Photo Films Co. Ltd, Jpn. Patent 6118659 (Chem. Abstract 1987106 166325); Tonomura Y and Handa J 1991 Mitsubishi Paper Mills Ltd Jpn. Patent 03126035 (Chem. Abstract 1991115 218921r)

7. Oota T, Yashioka K, Akyama T and Mori S 1995 Jpn. Patent 07205548 (Chem. Abstract 1995 $123325855 \mathrm{j}$ )

8. Narayan S $1999 \mathrm{Ph}$ D thesis, Mumbai University

9. Jain V K, Kannan S, Butcher R J and Jasinski J P 1993 J. Chem. Soc., Dalton Trans. 1509

10. Jain V K, Kannan S and Tiekink E R T 1994 J. Chem. Res. (S) 85; 1994 J. Chem. Res. (M) 501

11. Singhal A, Jain V K, Varghese B and Tiekink E R T 1999 Inorg. Chem. Acta 285190

12. Dey $\mathrm{S}$ and Jain V K (unpublished results)

13. Loknath N K, Prasad S J, Narayan S and Jain V K (unpublished results)

14. Narayan S, Jain V K and Varghese B 1998 J. Chem. Soc., Dalton Trans. 2359

15. Singhal A and Jain V K 1995 J. Organomet. Chem. 49475

16. Singhal A, Jain V K, Mishra R K and Varghese B 2000 J. Mater. Chem. (in press)

17. Narayan S, Jain V K and Butcher R J 1998 Polyhedron 172037

18. Narayan $S$ and Jain V K (unpublished results)

19. Fong S W A and Hor T S A 1999 J. Chem. Soc., Dalton Trans. 639

20. Narayan S and Jain V K 2000 Trans. Metal. Chem. (in press)

21. Jain V K (unpublished results) 